\title{
INSTRUCÇÃO MILITAR \\ DA \\ FACULDADE DE DIREITO DE SÃO PAULO
}

Exm.o Snr Dr. Antonio Iino da Costa Bueno. D. Director da Faculdade de Direito

\section{RELATORIO}

Tenho a honra de vos apresentar o presente relatorio, sobre a instrucção militar dos alumnos no corrente anno lectivo.

Início da instrucção. A instrucção teve inicio com a abertura das aulas do curso juridico em Abril do corrente anno. De accordo com o horario organisado pela Secretaria, a instrucção foi dada diariamente, de I ás 3 horas da tarde as segundas-feiras, para $\mathrm{O} \mathrm{I}^{\circ}$ e $2^{\circ}$ anno; de $\mathrm{I}$ ás 2 para os outros annos, excepto ás quintas-feiras, reservadas para exercicio de tiro ao alvo, na linha de tiro. Pará cada anno abri a instrucção, encarecendo a sua vantagem, 
já para o engrandecimento da Patria, já para o interesse individual de cada um.

Frequencia. Muito frequentada no começo, foi depois escaceando, chegando ao ponto de não se ter mais de 8 a Io alumnos, em forma, nos $1 .{ }^{\circ} 2 .^{\circ} 3 .^{\circ}$ e $4 .^{\circ}$ annos; sendo que no $50^{\circ}$ anno, apresentavam-se sempre. cerca de 30 , para os exercicios. Para que a instrucção militar seja, neste estabelecimento, de facto obrigatoria, penso ser necessario, se fazer, como se faz nos collegios equiparados: reverter em perda do anno, as faltas dadas na instrucção. Pois a não ser assim, só frequentam os alumnos prestes a terminar o curso, como meio de isentarem-se do serviço militar obrigatorio.

Fardamento. Não houve uniformidade na instrucção, por não ter sido possivel adoptar um fardamento, pois isto viria acarretar mais uma despesa para os alumnos, o que não é possivel, attendendo aos seus recursos.

Todavia notei, que se sujeitariam a uzar o uniforme, sómente nos exercicios, desde que o Governo Federal, fornecesse pelo Ministerio da Guerra o fardamento Kaki.

Armamento. O armamento para a instrucção foi obtido pelo Senhor Director, do Governo do Estado, por emprestimo até ter o estabelecimento proprio. Foi conservado e limpo por um cabo do exercito.

Munições. Recebi a necessaria instrucção de tiro ao alvo dos alumnos do $5 .^{\circ}$ anno.

Auxiliar da instrucção. Depois das aulas encerradas apresentou-se o aspirante o official Faustino Candido Gomes, nomeado para me auxiliar.

Linha de tiro. Sendo muito affastadas da cidade e de communicação difficil as linhas das Sociedades 
nrs. 2 e 3 , obrigadas a franquearem aos alumnos quando acompanhados do instructor, fui levado a apropriar, com permissão do respectivo dono, a velha linha do Bosque da Saude, tendo feito para isso algumas despesas, afim de alli fazerem os exercicios os alumnos do $5 .^{\circ}$ anno.

Sala de armas. Em uma das dependencias do edificio, foi preparada, confortavel e commodamente uma bôa sala, para deposito doarmamento e respectivos trabalhos.

Area para exercicio. Os exercicios deste anno, foram feitos em uma arêa interna, muito acanhada e em logar que perturba os trabalhos da administracção. Acho de grande conveniencia e necessidade se preparar a grande arêa em que se acha o jardim para ahi se realisarem os exercicios. Alem de não acarretar grande despesa, tem a vantagem de ser isolada do resto do estabelecimento, não prejudicando outros trabalhos e não sendo tambem prejudicada, como foi, a instrucção.

Ultimos exercicios. Com a presença do Senhor Major Doutor José de Assis Brazil, representando o Senhor General de Divisão Doutor Antonio Vicente Ribeiro Guimarães, Inspector da Io. ${ }^{a}$ Região Militar, realisaram-se os ultimos exercicios, de evolução e tiro ao alvo, respectivamente nos dias I I e I 2 de Novembro do corrente anno, tendo a elles, comparecido os 27 alumnos do $5 .^{\circ}$ anno, que satisfizeram as exigencias do artigo 177 do Regulamento do Alistamento e Sorteio Militar, aos quaes serão, opportunamente entregues a caderneta de reservistas de 2. ${ }^{2}$ cathegoria, a que fizeram jus. Foi este estabelecimento de ensino o primeiro em todo o Brazil, que deu cumprimento as disposições do referido artigo 177 , apre- 
sentando a ${ }^{\text {a }}$ turma de reservistas academicos, pelo que teve da alta administração militar, os mais francos elogios. No livro respectivo da instrucção militar, se acha averbada a relação nominal dos 27 alumnos que fizeram jus a caderneta de reservistas do Exercito.

São Paulo, I 4 de Dezembro de 1909.

(Assignado) Daniel de Scuza Ramos.

2. Tenente Instructor 